\title{
Livedo racemosa: a cutaneous manifestation of Sneddon's syndrome
}

\author{
Irene Timoney, ${ }^{1}$ Aoibheann Flynn, ${ }^{2}$ Niamh Leonard, ${ }^{3}$ Bairbre Wynne ${ }^{4}$
}

'Dermatology, Sligo University Hospital, Sligo, Ireland 2Dermatology, Mater Misericordiae University Hospital, Dublin, Ireland ${ }^{3}$ Histopathology, St. James's Hospital, Dublin, Ireland ${ }^{4}$ Dermatology, St. James's Hospital, Dublin, Ireland

\section{Correspondence to} Dr Irene Timoney; irenetimoney@gmail.com

Accepted 21 October 2019

\section{DESCRIPTION}

A 26-year-old woman presented to the emergency department with severe headache and blurred vision. On examination, she was suffering a hypertensive crisis, with a blood pressure of $240 / 115$. She underwent numerous investigations for hypertension, all of which were negative. Following a 3-week admission, her blood pressure was controlled with the use of several antihypertensive agents.

Three years later, she underwent investigation for intermittent episodes of unilateral weakness and numbness. An MRI brain demonstrated white matter changes suggestive of a vasculitis. Full stroke workup was otherwise negative. The patient reported a 2-year history of a skin eruption and dermatology was consulted. On examination, a widespread mottled rash was present, consistent with livedo racemosa (figure 1).

Livedo racemosa describes a reddish-blue mottling of the skin in an irregular, reticular pattern. It differs from the more common livedo reticularis by its shape. Livedo racemosa consists of broken circular segments resulting in a seemingly larger pattern, as opposed to the fine, regular, complete network of livedo reticularis. Livedo racemosa results from permanent impairment of peripheral blood flow and, unlike livedo reticularis, it persists on warming.

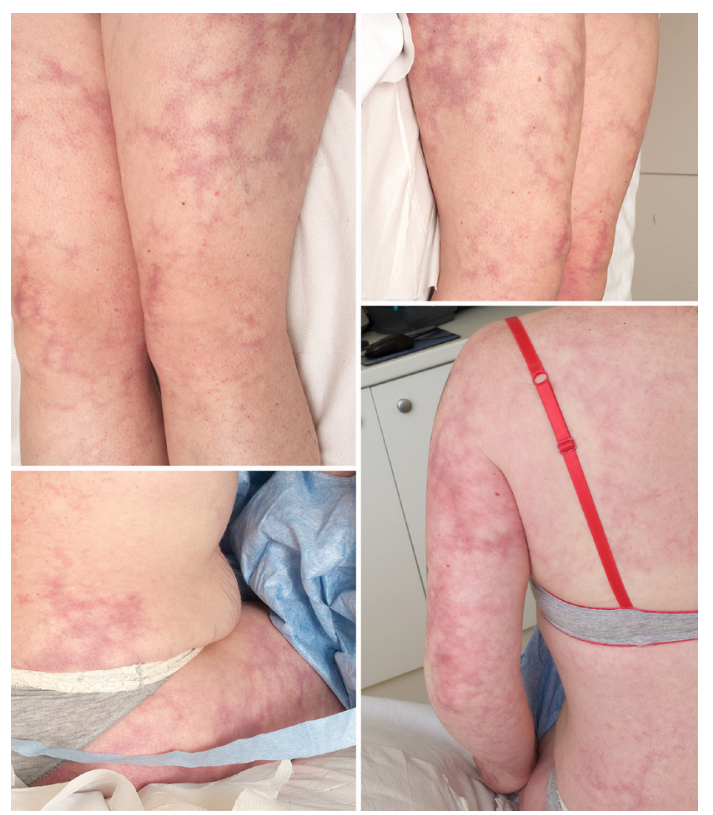

Figure 1 Clinical photograph demonstrating widespread livedo racemosa with persistant, violaceous, mottled discolouration of the skin.

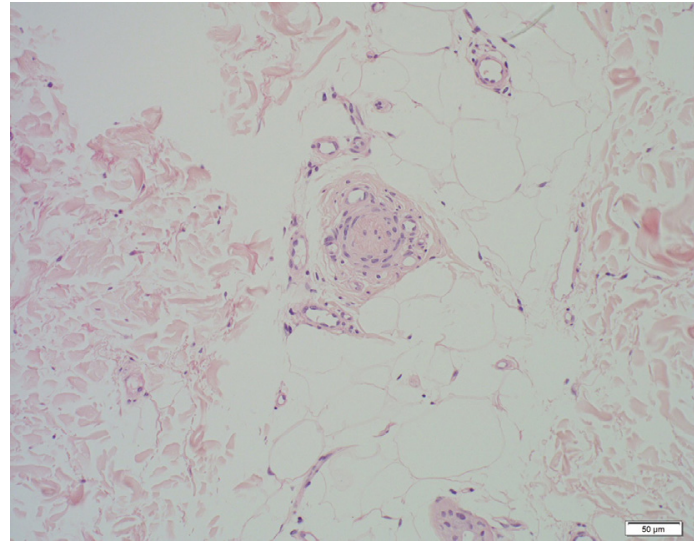

Figure 2 Histopathological examination supported a diagnosis of Sneddon's syndrome. This image demonstrates an occluded blood vessel in the subcutis with neovascularisation.

Given the combination of livedo racemosa, neurological symptoms, hypertension and white matter changes on MRI brain, a diagnosis of Sneddon syndrome was suspected.

Antiphospholipid syndrome was considered in the differential diagnosis, however, beta 2 microglobulin, anticardiolipin antibodies, antinuclear antibodies, extractable nuclear antigen panel and antineutrophil cytoplasmic antibodies were all negative. She did have a positive lupus anticoagulant on one occasion but repeat testing on four subsequent occasions was negative.

Skin biopsy demonstrated myointimal hyperplasia of arterioles in the dermis and subcutis, with surrounding neovascularisation and occlusion of one arteriole (figure 2). Following review by haematology, she was commenced on aspirin $150 \mathrm{mg}$ once daily.

Sneddon syndrome is a rare, non-inflammatory vasculopathy characterised by the association of cerebrovascular disease with livedo racemosa. Sneddon syndrome is more common in women and has an incidence of four per one million per annum in the general population. ${ }^{1}$ The syndrome usually occurs sporadically, although a few familial cases have been reported. Neurological manifestations, consisting of ischaemic events (either stroke or transient ischaemic attack) are a hallmark of the disorder with onset usually occurring before the age of 45 years. Headache is the most common nonspecific symptom. Vascular risk factors are often present in these patients and arterial hypertension is a frequent association. ${ }^{2}$

Recurrent ischaemic events can lead to functional disability, cognitive dysfunction and psychiatric disturbance. Management includes control of 


\section{Learning points}

Sneddon's syndrome is a rare disorder that most commonly affects young women and is characterised by livedo racemosa and central nervous system disease.

- Livedo racemosa is differentiated from the more common livedo reticularis by its shape and pattern in addition to its persistence on warming. Livedo racemosa in Sneddon syndrome is widespread and almost always involves the trunk and/or buttocks.

- Ischaemic events such as stroke and transient ischaemic attack are a hallmark of Sneddon's syndrome. Headache and hypertension, as in this case, are commonly associated with the condition. vascular risk factors and treatment with aspirin or warfarin to prevent vascular coagulopathy.

Contributors IT: prepared and revised manuscript, obtained informed patient consent, organised photographs, involved with treatment of patient. AF: registrar who also saw this patient initially and was involved in investigation and treatment, performed biopsy. NL: consultant histopathologist who reviewed histopathology and assisted in diagnosis. BW: treating consultant with overall responsibility for investigation and treatment of patient.

Funding The authors have not declared a specific grant for this research from any funding agency in the public, commercial or not-for-profit sectors.

Competing interests None declared.

Patient consent for publication Obtained.

Provenance and peer review Not commissioned; externally peer reviewed.

\section{REFERENCES}

1 Wu S, Xu Z, Liang H. Sneddon's syndrome: a comprehensive review of the literature. Orphanet J Rare Dis 2014;9:215. 
Copyright 2019 BMJ Publishing Group. All rights reserved. For permission to reuse any of this content visit https://www.bmj.com/company/products-services/rights-and-licensing/permissions/

BMJ Case Report Fellows may re-use this article for personal use and teaching without any further permission.

Become a Fellow of BMJ Case Reports today and you can:

- Submit as many cases as you like

Enjoy fast sympathetic peer review and rapid publication of accepted articles

- Access all the published articles

Re-use any of the published material for personal use and teaching without further permission

Customer Service

If you have any further queries about your subscription, please contact our customer services team on +44 (0) 2071111105 or via email at support@bmj.com. Visit casereports.bmj.com for more articles like this and to become a Fellow 